\title{
The Effect of the Financial Crisis on Investment Projects Case Study: Kurdistan Region of Iraq
}

\author{
Amanj Jalal Faiq \\ College of Administration and Economic \\ University of Human Development \\ Sulaimani, Iraq \\ amani.faiq@uhd.edu.iq
}

\begin{tabular}{l} 
Article Info \\
Volume 6 - Issue 2- \\
December 2021 \\
DOI: \\
10.24017/science.2021.2.10 \\
Article history: \\
Received 28/8/2021 \\
Accepted 14/9/2021 \\
\hline
\end{tabular}

Keywords:

Financial Crisis, Investment projects, Domestic and Foreign Investment, Kurdistan Region-Iraq

\begin{abstract}
Domestic and international investments are critical for a country's economic growth since they facilitate the transfer of technology, job creation, increase the exports of goods, and services. The financial crisis in Kurdistan region has several economic consequences for domestic and foreign investments, especially on the investment projects throughout: the rate of capital, the numbers of projects, the rate of sectors distribution, nationality investors and the distribution of projects on governors. Since 2014, the Kurdistan region faced financial and economic crisis, which had a huge negative effect on investment projects. As a result, the influence of the investment projects of economic development suffered from fluctuation and instability. This study attempts to evaluate the effect of financial crises on investment projects in Kurdistan regional which are implemented by domestic and foreign investors. To accomplish this objective the statistical technique and economic analysis was applied for annual time series data from 2006 to 2017 by applying the compound annual growth rate Gordon growth model (CAGR). This study finds that the financial crisis has a huge negative effect on local and international investment initiatives during the last decades.
\end{abstract}

Copyright (C) 2021 Kurdistan Journal of Applied Research. All rights reserved.

\section{INTRODUCTION}

The investment environment has improved significantly over the last two decades, owing in part to increased awareness of the advantages of foreign direct investment (FDI), which has expanded quickly across the global economy, especially, in developing countries. Most of the 
developing countries have become part of the international economic and the place for attracting FDI. Thus, the large volume and diversity of FDI serve as a critical lever for increasing global economic integration. The advantage of investment, particularly FDI, stems from its impact on a country's economic growth via technology and know-how transfer, export promotion, and positive effects on the commerce and balance of payments through recruiting and training available labor. The global crisis is manifested by a restriction on access to financial resources, including loans and sources of capital, a decline in profits as a result of sales declines, and thus a reduction in financing resources devoted to self-financing activities, acquisitions, and mergers at the international level, as well as the principles of strong economics based on cooperation. After 2013, Kurdistan region has suffered from the higher financial crisis since the fall of previous regime. 2014 marked the end of the growth rated in local and foreign investments in whole economic sectors that started in 2006 and Kurdistan investment projects flows reach a historic record of 40 billion USA dollars in 2013. Due to the impacts of continues Kurdistan financial crisis on local and foreign direct investment (FDI) flow has brought several consequences; such as decrease number of projects, inter of rising unemployment, growth slowdown, a substantial decline in international capital flows and a shift in the direction of trend capital flows to economic sectors as a primary outcome of previous financial crises.

This study tries to evaluate the effect of financial crises on investment projects in Kurdistan region which are implemented by domestic and foreign investors through the Board of Investment which are licensed under the law No: 4 of 2006. Also, finding out a trend of investment projects and investment environment in Kurdistan region by considering how financial crises influence Kurdistan economic development through analysis and comparison and providing some recommendation for Kurdistan region development specially to excesses in financial crises.

A research question raised in this study is to what extend does the investment projects influenced by the current financial crises. Based on the related literature and to achieve the aims of the study it is hypothesized that; the financial crisis has a negative effect on economic growth through investment projects.

\section{LITERATURE REVIEW}

The financial crises have not only generated through losing financial market, but also through the main economic aggregates such as gross domestic production (GDP) growth and investment. Consequently, Numerous studies have shown that the financial crisis had a ripple effect on other sectors, most notably the economic sector. For instance, the sub-prime crisis was sparked by a financial issue in the United States housing market, establishes a serious effect on all United States economic sectors and the global economy as well, particularly growth and the investment [1].

Additionally, FDI is a kind of capital flow that finances local investment, particularly in nations with little resources. Additionally, it adds to the import of modern technology and encourages sophisticated management, which drives development. [2] demonstrated that capital flows may act as a source of investment, particularly for nations with little resources. Further, it adds to the import of modern technology and encourages sophisticated management, which drives development. Economic growth is shown in the literature to rise with both capital accumulation and high efficiency of investment.

Athukorala [3] identified that financial Crises creates a detrimental impact on the activities of multinational corporations in crisis-affected economies. He identified three adverse impacts of currency collapse on FDI. Massive depreciations lower domestic manufacturing costs, making countries more appealing to export-oriented foreign investors. FDI becomes more lucrative as a result. A second impact would be a reduction in investment expenses as a result of lower asset costs when demand declines. Finally, the anti-crisis package and new foreign control laws may open up new possibilities for acquisitions and mergers. Negative impacts may be 
defined as those that have a detrimental influence on domestic market-oriented foreign investment.

During crises, the behavior of the subsidiaries of transnational companies was more stable in compare to the local firms even during non-crisis period. Chen and Alfaro foreign businesses [4] responded more strongly to crises than domestic firms, even though they had comparable economic features, since overseas firms usually get financial assistance from their foreign parent corporations when they confront a tough financial and credit position in the host nation. When a crisis arises solely in the host nation, ties to the parent firm provide more stability, since the mother company is unaffected by the local crisis.

On the other hand, although some research highlights FDI's greater stability relative to other forms of capital, others argue in the other direction. For example, Claessens et al. [5] demonstrate that FDI volatility is similar to that of other types of investment. Also, Reinart and Rogoff [6] outlined the characteristics of the financial crisis that struck 18 developed countries in 2008. Given the relative insignificance of crises, they focused on those that happened in five countries and had a disproportionate impact: Spain (1977), Norway (1987), Finland (1991), Sweden (1991), and Japan (1991). (1991). (1992). The study's findings corroborate three typical features of financial crises: a sharp decline in asset values, a significant decline in output and an increase in unemployment, and an alarming growth in public debt.

The financial crisis acted as a sobering reminder of the government's policy shortcomings. The effectiveness of government policies - both domestic and international - in handling the financial crisis and its economic consequences is essential for creating conditions favorable to a fairly fast recovery in both FDI flows and economic growth [7].

Consequently, although few studies have attempted to objectively analyze the unusual behavior of bilateral FDI flow after financial crises, [8] showed that FDI remained relatively stable throughout the 1982 Latin American, 1994 Mexican, and 1997 East Asian crises.

The collapse of economic sectors, particularly private ones, as a result of local and global financial crises has generated considerable interest in determining the causes and effects, both experimentally and conceptually. Prior to the 1990 Japanese asset price crisis, the 1997-1998 Asian financial crisis, the 2000 to 2001 dot-com bubble burst crisis, and the robust economic growth and attractive stock returns in a variety of regions throughout the world, foreign investors redirected their funds to those regions' financial and capital markets [8].

Numerous studies, on the other hand, have studied the financial crisis's effect on economic growth and the investment process. Indeed, as [9] and [10] found, financial crises decrease investment incentives, slow the pace of demand, especially for products, and raise uncertainty about capital and risk premium returns. On the other hand, the majority of businesses face less favorable financing circumstances as a consequence of tighter lending criteria, rising borrowing rates, and a restricted availability of credit.

Cerra and Saxena [11] shown that political or financial crises account for more than half of all economic crises; their research relies on low-income nations as a significant source of conflicting data on postwar development. Becker and Mauro [12] discovered that financial shocks and macroeconomic linkages are more expensive for emerging nations (in terms of yearly GDP per capita losses), and that trade shocks and interest rates are detrimental to emerging nations.

According to Reinhart and Rogoff [13], previous financial crises have had a detrimental longterm impact on economic growth. This finding is corroborated by [5]. Additionally, the same research discovered that international crises, particularly financial crises, had a far stronger impact (at least twice as strong) on the level of employment and output than regular crises.

On the other hand, academics assert that the current financial and economic crisis may provide some helpful insights. Indeed, [14] shown that crises have a range of impacts on economic potential. They examine the post-crisis era and discover that half of nations improve their potential development. Additionally, increase in factor productivity seems to be a significant element explaining the variation in potential growth rates across nations. According to the 
approach proposed by [15], this quantifies the impact of financial crises on GDP. GDP dropped by an average of 1.5 percent to 2.4 percent after a crisis. The decline spans five years. Finally, financial crises have a detrimental impact on both the financial industry and the whole economy. It has spread from nation to country and region to region, wreaking havoc on the level of activity in industrialized countries, rising economies, and developing economies. For example, the previous recession resulted in decreased industrial output, and foreign commerce, including the United States, contributed to the developed world's worst recession since the conclusion of World War II. The crisis in the economy of industrialized nations has resulted in a decrease in demand for raw resources and commodities. This has a detrimental effect on emerging nations, exposing them to the risk of economic catastrophe

\section{PREVIOUS CRISIS AND THE EVOLUTION OF INVESTMENT}

This section must include good technical information to allow the experiments to be repeated. The sources of all media (like name and location of manufacturer) or components of a new formulation must be provided.

\subsection{The Latin America Crisis of 1982}

According to [8] after starting the Latin American currency crisis in 1982, all types of inward investment gradually declined. This crisis resulted in a decline in regional investment flows. FDI continues to be good, even though it will reach pre-crisis levels in 1988. Rather than that, portfolio assets saw a decline in value in 1983 and began to recover only in 1988.

Kiminsky and Reinhart [16] demonstrated that Latin America suffered from financial crises more than any other emerging region between 1970 and 1995; They found that financial crises had a greater impact on Latin America than on western and Asian countries by more than $50 \%$. Additionally, the characteristics of the crisis vary considerably by region; for instance, the East Asian crisis has certain characteristics with the Latin American crisis (volatile capital flows and a weak financial system). Additionally, Lipsey [8] observed that FDI had a smaller drop than other types of investment during the Latin American crisis. However, Mexico's crisis was similar; FDI flows decreased, albeit much less than other kinds of capital, and never reached a negative level. On the other hand, FDI inflows into East Asia decreased somewhat in 1998 but increased significantly in 1999.

Generally speaking, the Latin America crisis of 1982 was survived by the world direct investment inflows. The manufacturing affiliates from U.S was contributed more than their share to the subsequent growth of exports and to their host countries' switching from local to export markets, on the other hand, they also moved faster than other host country firms to abandon local, host country, markets until these recovered.

\subsection{The Global Financial Crisis During 2008-2009}

The financial crisis that began in 2007 was characterized by a decline in foreign direct investment, making it the most severe financial catastrophe since the Great Depression of 1930. It is characterized by fast global spread. Due to the rapidity with which it happened, in addition to the aforementioned components or separate regions, varied intensities evolved over time [7].

The global financial crisis began in the United States of America as a sub-prime mortgage crisis, which rapidly extended to the country's entire financial sector and subsequently to nonfinancial sectors worldwide. According to UNCTAD 2009, the global financial crisis in 2009 resulted in the collapse of FDI flows globally, which had reached a record 2 trillion dollars in 2007 as a consequence of four years of expansion; furthermore, FDI fell by more than $14 \%$ at the global level in 2008 .

The financial crisis disproportionately impacted rich nations, with a 30\% drop in 2008; nevertheless, developing countries continued to receive FDI at a rate of more than $17 \%$ in 2008 , compared to 2007. Globally, FDI fell by more than $30 \%$ in 2009 compared to 2008 . On the other hand, the financial crisis did not impact developing nations in 2009, and as a result, the majority of countries have attempted not only to attract new investment and capital flows, but also to retain current ones [17]. 
Miles Ferretti and Tille recognized three different phases of the crisis [18]. The first started in August 2007 with the explosion of the Lehman Brothers issue; the second began in September 2007 with the collapse of the Lehman Brothers issue, which resulted in a decline in foreign capital flows into developed nations' banking systems. The second stage, which lasted from late 2008 to early 2009, was marked by capital repatriation, particularly banks loans. The last stage started in the second half of 2009, when non-flows and banking in Latin America and Asia saw a modest recovery.

Poulsen demonstrated that the financial crisis began in the United States of America and Europe and then extended to the rest of the world [1]; he also shown that the greatest decrease is occurring in mergers and acquisitions in emerging nations. All FDI components saw decreases in 2008, although the most significant one was the one reported by equity investments, indicating that the recovery of FDI flows may continue for some time.

According to the UNCTAD report 2009 [17], the decline in global FDI since the financial crisis of 2008 is due to a number of factors, including the financial crisis itself, the decline in the stock market, the decline in funding capabilities due to the increase in the cost of credit, the decline in global demand, and the decline in corporate profitability. Additionally, Hill and Jongwanich [19] demonstrated that portfolio investment started to decline only in late 2008, remaining relatively stable and progressively increasing in 2009. In comparison to the Asian crises, portfolio investment dropped precipitously.

\section{KURDISTAN REGION: POLITICAL AND ECONOMIC CHALLENGES}

According to the OECD study [20], Iraq is in a state of internal strife and change almost 15 years after Saddam Hussein's Baathist government fell. Institutions and governance systems continue to be frail and insecure. Iraq's stabilization and reconstruction process has been inconsistent; in general, international investment inflows and the business environment have been relentlessly denigrated. Iraq remains a highly polarized state along ethnic and religious lines, with high levels of conflict. Since 2003, the primary focus of political debate has been on containing persistently high levels of sectarian violence in large parts of the country and implementing the Constitution, which recognizes Iraqi Kurdistan as a federal region with a broad range of executive powers. Above all, the calculation of the Kurdistan Regional Government's (KRG) agreed 17 percent share of the national budget and the management of oil resources have been contentious in talks between the KRG and the Iraqi central government.

The KRG enacted a distinct Kurdistan oil and gas legislation in 2007. Additionally, the KRG signed contracts with foreign oil firms that are being challenged by the federal government. Tensions with the KRG have risen since July 2015, when it began exporting oil without informing or paying the central government and publicly discussed organizing an independence referendum.

Iraq's position deteriorated further in June 2014, as the Islamic State (IS) advanced into northern Iraq, escalating already-existing tensions and difficulties. Although IS seems to have been contained, the organization still controlled significant portions of Iraq in June 2016 and had the capability to launch offensives and destabilize the nation [20]. Previously, the KRG faced a military battle against IS, a resulting humanitarian catastrophe, central government budget cuts, decreased oil prices, and local strife between various political parties.

As a result, KRG has hit by a deep financial crisis since 2014, has made many consequences on the whole economic and people, in particular on private sectors and investment projects. After 16th October 2017, the KRG faced with lost most of revenue sources such as many big oils field, airport authority, trading and tariff-customs and even foreign loan and outside supports. Currently, day by day, KRG conflict with a big crisis. 


\section{KURDISH BOARD OF INVESTMENT}

The investment procedure in Iraqi Kurdistan is governed by the KRG Investment Law No. 4 of 2006, which governs non-hydrocarbon projects (hydrocarbon projects falling under the Kurdistan Oil and Gas Law of 2007). The Kurdistan Region Investment Promotion Law No. 4 of 2006 was established to promote investment in the Kurdistan Region. It aims to remove legal barriers and to promote domestic and foreign capital investment in a range of development projects that contribute to the region's economic development process. Numerous incentives are provided in the form of amenities and tax cuts to promote investment in the region [21].

\section{RESULT AND ANALYSIS}

The study of data and information is based on the compound annual growth rate (CAGR) Gordon growth model and model estimation through the Autoregressive Distributed Lag (ARDL) method with the stationary test, since they are relevant measures of growth across various time periods. It may be viewed of as the growth rate that takes you from the original investment value to the final investment value, assuming that the investment compounded through time. The CAGR formula is presented in Equation (1).

$$
C A G R=(I E V / I B V) 1 / n-1
$$

Where:

IEV = Investment's final value.

IBV = Investment's first value.

$\mathrm{n}=$ period of time (months, years, etc.).

Kurdistan region hit a deep financial crisis at the beginning of 2014, we are going to compare between the periods before the financial crisis (2006-2013) and, the periods of financial crisis (2014-2017), and however, the financial crisis still continues. Table 1 gives a general information of investment projects from 2006-2017 in Kurdistan Region of Iraq provided by the Kurdish Board of investment. The total project is 713 projects which are distributed on three main governorates and the total capital has reached more than 46 billion us dollars.

Table 1: general information of investment projects from 2006-2017 in Kurdistan Region of Iraq [21]

\begin{tabular}{ccccccc}
\hline Governorate & $\begin{array}{c}\text { No. } \\
\text { licenses }\end{array}$ & $\begin{array}{c}\text { Capital in } \\
\text { dollar }\end{array}$ & $\begin{array}{c}\text { Area in } \\
\text { donums }\end{array}$ & $\begin{array}{c}\text { National } \\
\text { investor`s }\end{array}$ & $\begin{array}{c}\text { Foreign } \\
\text { investor`s }\end{array}$ & $\begin{array}{c}\text { Joint- } \\
\text { venture`s }\end{array}$ \\
\hline Erbil & 345 & $26,215,540,812$ & 31,469 & 298 & 35 & 12 \\
\hline Sulaimani & 215 & $13,721,616,780$ & 16,859 & 204 & 1 & 10 \\
\hline Duhok & 230 & $6,458,712,372$ & 13,194 & 211 & 10 & 9 \\
\hline Total & 790 & $46,386,869,964$ & 61,522 & 713 & 46 & 31 \\
\hline
\end{tabular}

Over the course of 8 years from 2006 to 2013 the investment grew from 438000.0 to 11761254.0. Its CAGR is 50.88. But from the beginning of financial crisis from 2014 to 2017 , the investment grew from 3962828.0 to 711173 .0. Its compound annual growth rate (CAGR) is $-34.91 \%$. It means the decrease of investment reached -34.91 through the crisis period. Table 2 presents the annual investment of capital in million dollars from (2006-2013) compared to (2014-2017) by using CAGR Formula.

Table 2: The annual investment of capital in million dollars from (2006-2013) compared to (20142017) by using CAGR model [21]

\begin{tabular}{c|c}
\hline $\begin{array}{c}\text { The period time before, and after financial } \\
\text { crises }\end{array}$ & $\begin{array}{c}\text { CAGR for investment projects by capital in } \\
\text { dollar (\%) }\end{array}$ \\
\hline $2006-2013$ & 50.88 \\
\hline $2014-2017$ & -34.91 \\
\hline
\end{tabular}

Over the course of 8 years before financial crisis the number of licensing projects grew from 2.0 to 118.0. Its (CAGR) is $66.48 \%$, but over 4 years of financial crises (2014-2017) the 
number of licensing investment projects were declined by more than -19.35 depending on CAGR model. Table 3 shows the annual investment of number of licensing projects from (2006-2013) compared to (2014-2017) by using CAGR model.

Table 3: The annual investment of number of licensing projects from (2006-2013) compared to (2014-2017) by using CAGR model [21]

\begin{tabular}{c|c}
\hline $\begin{array}{c}\text { The period before, and after financial } \\
\text { crises }\end{array}$ & $\begin{array}{c}\text { CAGR for investment projects by number of } \\
\text { Projects licensing (\%) }\end{array}$ \\
\hline $2006-2013$ & 66.48 \\
\hline $2014-2017$ & -19.35 \\
\hline
\end{tabular}

Over the course of 8 years, before of financial crises the investment at all sectors grew in different range, for example, the industrial sector grew so rapidly from 1.0 to 700000000.0 . Its (CAGR) is $1175.37 \%$. Meanwhile, some other sectors have grown at lower range such as trade and education sectors. On the other hand, over the course of 4 years of financial crises the all sectors have affected by different range, additionally, the financial crisis has affected all sector and led to decrease of capital inflow over the all sectors, for example, the sector of art, transportation and communication having not been received any projects. So, many other sectors have affected in lower rang such as industrial and agricultural sectors: the capital flow at industrial sector for financial crisis period has grown from 10173881.0 to 240000000 .0. Its compound annual growth rate (CAGR) is $120.38 \%$. Additionally, over the course of 4 years of financial crises the investment at agricultural sector grew from 3252032.0 to 150000000.0 . Its compound annual growth rate (CAGR) is $160.61 \%$. Additionally, Over the course of 8 years before financial crisis the housing sector one of the most profitable sector which are at the top of other sectors for capital and number projects but, for 4 years of financial crises; does not show any result because the housing sector are not received any new project as a result of its not giving new licensing by KRG from 2012. Table 4 shows the annual investment by capital - sectors in dollar from (2006-2013) compared to (2014_2017) by using CAGR model $(\%)$.

Table 4: The annual investment by capital - sectors in dollar from (2006-2013) compared to (20142017) by using CAGR model (\%) [21]

\begin{tabular}{c|c|c|c|c}
\hline No. & Sectors & Total capital 2006-2018 & $\mathbf{2 0 0 6 - 2 0 1 3}$ & $\mathbf{2 0 1 4 - 2 0 1 7}$ \\
\hline $\mathbf{1}$ & Industry & $16,702,400,322$ & 1175.37 & 120.38 \\
\hline $\mathbf{2}$ & Agriculture & $837,052,066$ & 531.32 & 160.61 \\
\hline $\mathbf{3}$ & Trading & $4,386,137,966$ & 25.28 & -2.67 \\
\hline $\mathbf{4}$ & Tourism & $6,724,817,355$ & 790.39 & -20.6 \\
\hline $\mathbf{5}$ & Housing & $14,985,787,204$ & 118.77 & - \\
\hline $\mathbf{6}$ & Educational & $727,359,739$ & 467.91 & -41.33 \\
\hline $\mathbf{7}$ & Services & $91,775,715$ & 663.57 & 25.55 \\
\hline $\mathbf{8}$ & Health & $918,611,662$ & 842.39 & -47.64 \\
\hline $\mathbf{9}$ & Communication & $220,890,942$ & 628.06 & - \\
\hline $\mathbf{1 0}$ & Banks & $756,682,661$ & 856.39 & -31.71 \\
\hline $\mathbf{1 1}$ & Art & $12,317,467$ & 593.47 & - \\
\hline $\mathbf{1 2}$ & Sports & $98,902,849$ & 529.09 & -28.69 \\
\hline $\mathbf{1 3}$ & Transportation & $104,204,000$ & 856.39 & - \\
\hline
\end{tabular}

Note:( -) it means for that period, there are no any projects have licensed by BOI

Over the course of 8 years, before of financial crises at Erbil governorate the investment grew from 1.0 to 5533382.0. Its (CAGR) is $596.42 \%$. Duhok governorate the second rang of capital inflow compared to Sulaimani is a last one, but over the course of 4 years of financial crises the Sulaimani governorate has affected more than any two other governorates of financial crisis even before crisis period, Sulaimani has received the lowest capital flows. Over the 
course of 4 years of financial crisis, the investment grew at Sulaimani governorate grew from 1308794.0 to 50362.0. Its compound annual growth rate (CAGR) is $-55.71 \%$. Table 5 represents the annual investment by capital - governorates in dollar from (2006-2013) compared to (2014-2017) by using CAGR model.

Table 5: The annual investment by capital - governorates in dollar from (2006-2013) compared to (2014-2017) by using CAGR model [21]

\begin{tabular}{c|c|c}
\hline Governorate & CAGR (2006-2013) & CAGR (2014-2017) \\
\hline Erbil & 596.42 & -38.58 \\
\hline Sulaimani & 33.49 & -55.71 \\
\hline Duhok & 500.34 & -5.67 \\
\hline
\end{tabular}

Over the course of 8 years the licensing projects number for Erbil governorate grew from 1.0 to 46.0. Its (CAGR) is $61.38 \%$. Meanwhile, Sulaimani governorate has received at lower rang compared by two other governorates. The licensing projects number for Sulaimani governorate grew from 2.0 to 37.0. Its (CAGR) is $44.01 \%$. But, over the course of 4 years of financial crisis, Sulaimani governor has affected more than any other governorate which its (CAGR) is $-28.38 \%$. Comparably, Erbil (CAGR) is -24.02, and Duhok (CAGR) is -14.63. Table 6 shows the annual investment by licensing projects - governorates from (2006-2013) compared to (2014_2017) by using CAGR model.

Table 6: The annual investment by licensing projects - governorates from (2006-2013) compared to (2014-2017) by using CAGR model [21]

\begin{tabular}{c|c|c}
\hline Governorate & CAGR (2006-2013) & CAGR (2014-2017) \\
\hline Erbil & 61.38 & -24.02 \\
\hline Sulaimani & 44.01 & -28.38 \\
\hline Duhok & 55.96 & -14.63 \\
\hline
\end{tabular}

Over the course of 4 years of financial crises the foreign type investment most effected compared with two other of nationality investments which are national and joint-venture types: the foreign investment grew from 66199.0 to 1.0. Its (CAGR) is $-93.77 \%$. Meanwhile the joint-venture stayed positively, its (CAGR) remain at positive grew at 25.07. However, over the course of 8 years, before of financial crises the all types of investment received the different positive ranges. (Table 7)

The annual investment by capital in dollar - investment type from (2006-2013) compared to (2014-2017) by using CAGR model

Table 7: The annual investment by capital in dollar - investment type from (2006-2013) compared to (2014-2017) by using CAGR model [21]

\begin{tabular}{ccc}
\hline Investment - type on capital & CAGR (2006-2013) & CAGR (2014-2018 \\
\hline National & 40.23 & -34.73 \\
\hline Foreign & 528.29 & -93.77 \\
\hline Joint-venture & 539.0 & 25.07 \\
\hline
\end{tabular}

Over the course of 8 years, the number of licensing projects for national investment most grew from 2.0 to 109.0. Its (CAGR) is $64.84 \%$. when over the course of 4 years of financial crises the number of licensing projects at national types is most effected, its (CAGR) is $-18.56 \%$. Table 8 presents the annual investment by licensing projects - investment type from (20062013) compared to (2014-2017) by using CAGR model. 
Table 8: The annual investment by licensing projects - investment type from (2006-2013) compared to (2014-2017) by using CAGR model [21]

\begin{tabular}{ccc}
\hline Investment - type on licensing projects & CAGR (2006-2013) & CAGR (2014-2018 \\
\hline National & 64.84 & -18.56 \\
\hline Foreign & 18.92 & -15.91 \\
\hline Joint-venture & 22.28 & 0.0 \\
\hline
\end{tabular}

\subsection{Model Specification and Estimation}

This section contains variable descriptions and model definition utilizing the Autoregressive Distributed Lag (ARDL) technique in conjunction with the stationary test.

\section{Variable descriptions}

To provide further information, the present research makes an effort to define all variables utilized in statistical analysis; these variables are as presented in Table 9.

Table 9: Description of variable and their sign

\begin{tabular}{clccc}
\hline $\begin{array}{c}\text { Variabl } \\
\text { es }\end{array}$ & Description & $\begin{array}{c}\text { The Sign according to } \\
\text { Theory }\end{array}$ & $\begin{array}{c}\text { The Sign } \\
\text { according to } \\
\text { literature }\end{array}$ & Expected sign \\
\hline CAP $\quad$ Project Capital (current US\$). & & & $(-)$ & $(-)$ \\
\hline FI $\quad$ Financial Crisis (0 and 1). & & & \\
\hline Note: & & & \\
- 0 denoted the events that have not happened. & & \\
-1 denoted the event happened.
\end{tabular}

\section{Model specification}

A functional form model can be expressed in Equation (2) to describe the connection between project capital and financial crisis:

$$
C A P=f(F I)
$$

As shown below, the functional Equation (3) may be converted into an econometric model by adding a drift parameter, the slop of an explanatory variable, and a stochastic error component.

$$
L C A P t=\beta 0+\beta_{1} F I t+U t
$$

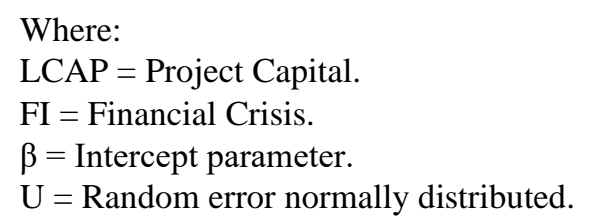

The coefficients are the model's parameters, and they describe the connection between Project Capital and Financial Crisis in terms of both its direction and intensity. The main coefficient of interest indicates the percentage change in Project Capital in reaction to a percentage change in Financial Crisis.

\section{Time series estimation by using $A R D L$}

The current study uses (ARDL) estimation methods to ascertain the financial crisis's effect on project capital. The variables are estimated with the use of E-views 9 and monthly data. 


\section{Stationary test Unit root test}

A stationary series is one whose mean is no longer time dependent. Numerous stationary tests have been published in the literature, including the Augmented Dickey-Fuller (ADF), Phillips-Perron (PP), and (KPSS) tests. The ADF and the PP are the two tests that are most often used in the literature. As a consequence, the ADF and PP unit root tests were employed in this study. The findings of the stationary test are summarized in Table 10.

Table 10: Unit root test result for Project Capital Phillips-Perron (PP)

\begin{tabular}{lccccc}
\hline \multicolumn{2}{c}{ Level } & \multicolumn{3}{c}{ First difference } \\
\hline Variable & Intercept & Trend & Variable & Intercept & Trend \\
\hline Project Capital & 0.0150 & 0.1176 & Project Capital & $0.0000^{*}$ & $0.0000^{*}$ \\
\hline \multicolumn{5}{c}{ Augmented Dickey-Fuller (ADF) } \\
\hline Variable & Intercept & Trend & Variable & Intercept & Trend \\
\hline Project Capital & 0.0150 & 0.1169 & Project Capital & $0.0000^{*}$ & $0.0000^{*}$ \\
\hline * and ** represents significant at $1 \%, 5 \%$ respectively. & & \\
Acceptance level of p-value is equal or less than 0.05. & \\
\hline
\end{tabular}

According to Table 10, at the $1 \%$ and $5 \%$ significance levels, Project Capital with log is stationary in the first difference (intercept and intercept with trend).

\subsection{Model estimation for Financial Crisis and Project Capital}

Estimation is the process of calculating an estimate or approximation, which is a numerical value that may be utilized for particular purposes despite the fact that the input data may be incomplete, inaccurate, or unstable. There are hundreds of techniques for estimation in the literature, but the most often used are ARDL. Thus, this research used ARDL methods, and the tables below illustrate the ARDL estimate results.

As seen in Table 11, (Financial Crisis) has a negatively signed coefficient. It demonstrates that the Financial Crisis had a negative and statistically significant impact on both long-and shortrun project capital. Thus, a one percent rise in (Financial Crisis) results in a 0.27 percent reduction in (Project Capital) in the short term, but this impact is considerably greater in the long run, equivalent to (-2.42 percent). By and large, the coefficient of the ECM term is 0.1126 , implying a gradual adjustment process. Thus, to maintain the long-term connection between the variables, the Project Capital should be increased by (0.8874).

Table 11: Model estimation result of relationship between financial crisis on project capital

\begin{tabular}{cccccc}
\hline Variables & Type of Variable & Coefficient & Std. Error & t-Statistic & Probability \\
\hline Beta $(\mathrm{C})$ & Constant & 21.7682 & 0.7528 & 28.9170 & 0.0000 \\
\hline \multicolumn{5}{c}{ ARDL Estimation/ short run effect } \\
\hline Variables & Type of Variable & Coefficient & Std. Error & t-Statistic & Probability \\
\hline $\begin{array}{c}\text { Project } \\
\text { Capital }\end{array}$ & Dependent Variable & & & \\
\hline $\begin{array}{c}\text { Financial } \\
\text { Crisis }\end{array}$ & $\begin{array}{c}\text { Independent } \\
\text { Variable }\end{array}$ & -0.2727 & 0.1320 & -2.0666 & 0.0405
\end{tabular}


ARDL Estimation/ long run effect

\begin{tabular}{|c|c|c|c|c|c|}
\hline Variables & Type of Variable & Coefficient & Std. Error & t-Statistic & Probability \\
\hline $\begin{array}{l}\text { Project } \\
\text { Capital }\end{array}$ & \multicolumn{5}{|l|}{ Dependent Variable } \\
\hline $\begin{array}{c}\text { Financial } \\
\text { Crisis }\end{array}$ & $\begin{array}{c}\text { Independent } \\
\text { Variable }\end{array}$ & -2.4209 & 1.3336 & -1.8154 & 0.0715 \\
\hline \multicolumn{6}{|c|}{ Equilibrium points for relationship between small project and family income } \\
\hline $\begin{array}{l}\text { Project } \\
\text { Capital }\end{array}$ & Financial Crisis & Coefficient & Std. Error & t-Statistic & Probability \\
\hline $\begin{array}{l}\text { Equilibrium } \\
\text { /ECM }\end{array}$ & ntegration) (-1) & -0.1126 & 0.0846 & -1.3315 & 0.1851 \\
\hline
\end{tabular}

Monthly Data from 2006 - 2018

The observation number is 146

The independent variable number is 1

\subsection{Statistical Indictors for Goodness of Fit}

tables, Checking the model and its goodness of fit is a critical stage in the estimate process. The aim of statistical validation is to ascertain the appropriateness of the employed technique. Table 12 below summarizes the statistical indicators. According to the same table, the ARDL models are adequately specified, since both the R2 and modified R2 are overly large. This result establishes that the model matches the data and is stated properly. As a result, the standard error (S.E.) in the ARDL model is (0.72), which is less.

Table 12: Statistical indicators and diagnostic tests and for the model

\begin{tabular}{cccccc}
\hline Indictors & R-Squared & Adjusted R $^{2}$ & $\begin{array}{c}\text { S.E. of } \\
\text { regression }\end{array}$ & $\begin{array}{c}\text { S.D. dependent } \\
\text { variance }\end{array}$ & $\begin{array}{c}\text { Durbin- } \\
\text { Watson stat }\end{array}$ \\
\hline Value & $=0.88$ & $=0.87$ & $=0.72$ & $=2.07$ & $=1.99$ \\
\hline
\end{tabular}

\section{CONCLUSION AND RECOMMENDATION}

The bulk of these research found a negative connection between crises and both growth and investment. Additionally, the duration of crises varies by kind and also across industrialized, developing, and early-development countries. Moreover, the present research demonstrates the cooperation of two distinct periods of financial crises in the Kurdistan region: eight years before to and four years during after financial crises. Financial crises have a major impact on investment approaches in a variety of ways, including the trend of capitals, sectors, governorates, investment type, and number of licensing projects. The impact of the Kurdistan region's financial crisis on the actual economy has remained largely unexplored, most likely due to the difficulties of conducting such an evaluation. Meanwhile, the KRG should adopt a variety of proactive legislative steps to bolster critical infrastructure and influence regional investment behavior. Although the area is abundant in natural resources, the question of who has the right to utilize them has not been resolved. Clarification of this matter is a high priority for the KRG. The Investment Law does exist, but it has not been examined or evaluated for its merits and weaknesses. For a variety of reasons, the legislation has been rather unsuccessful in attracting productive inbound FDI and encouraging total investment. Along with being an attractor of FDI, the newly improved banking sector may result in a rising trend in outbound FDI. Governance is ineffectual, and the majority of institutions are in existence but ineffective. 


\section{REFERENCES}

[1] L. Poulsen and G. Hufbauer, "Foreign direct investment in times of crisis," Transnatl. Corp., vol. 20, no. 1, pp. 19-38, 2011.

[2] E. Borensztein, J. De Gregorio, and J.-W. Lee, "How does foreign direct investment affect economic growth?," J. Int. Econ., vol. 45, no. 1, pp. 115-135, 1998

[3] P. Athukorala, "Foreign direct investment in crisis and recovery: Lessons from the 1997-1998 Asian crisis," Aust. Econ. Hist. Rev., vol. 43, no. 2, pp. 197-213, 2003.

[4] L. Alfaro and M. X. Chen, "Surviving the global financial crisis: foreign direct investment and establishment performance," Harvard Bus. Sch. BGIE Unit Work. Pap., no. 10-110, 2010.

[5] S. Claessens, M. P. Dooley, and A. Warner, "Portfolio capital flows: hot or cold?," World Bank Econ. Rev., vol. 9, no. 1, pp. 153-174, 1995.

[6] C. M. Reinhart and K. S. Rogoff, "Is the 2007 US sub-prime financial crisis so different? An international historical comparison," Am. Econ. Rev., vol. 98, no. 2, pp. 339-344, 2008.

[7] M. Lupan, "The evolution of the globalization and its impact on the investment process," USV Ann. Econ. Public Adm., vol. 10, no. 3, pp. 180-188, 2011.

[8] R. E. Lipsey, "Foreign direct investors in three financial crises," National Bureau of Economic Research Cambridge, Mass., USA, 2001.

[9] R. S. Pindyck, "Irreversibility, uncertainty, and investment," National Bureau of Economic Research Cambridge, Mass., USA, 1990.

[10] R. S. Pindyck and A. Solimano, "Economic instability and aggregate investment," NBER Macroecon. Annu., vol. 8, pp. 259-303, 1993.

[11] M. V. Cerra and M. S. C. Saxena, Eurosclerosis or financial collapse: why did Swedish incomes fall behind? International Monetary Fund, 2005.

[12] T. Becker and P. Mauro, "Output drops and the shocks that matter," 2006

[13] C. M. Reinhart and K. S. Rogoff, "The aftermath of financial crises," Am. Econ. Rev., vol. 99, no. 2, pp. 466-472, 2009.

[14] G. J. Koopman and I. P. Szekely, "The financial crisis and potential growth: Policy challenges for Europe," ECFIN Econ. Br., vol. 3, pp. 59-66, 2009.

[15] V. Cerra and S. C. Saxena, "Growth dynamics: the myth of economic recovery," Am. Econ. Rev., vol. 98, no. 1 , pp. 439-457, 2008.

[16] G. L. Kaminsky and C. M. Reinhart, "Financial crises in Asia and Latin America: Then and now," Am. Econ. Rev., vol. 88, no. 2, pp. 444-448, 1998.

[17] U. CTAD, "Assessing the impact of the current financial and economic crisis on global FDI flows," in United ations Conference on Trade and Development. U CTAD/DIAE/IA/2009/3. Geneva, April, United ations Publication, 2009.

[18] G. M. Milesi-Ferretti and C. Tille, "The great retrenchment," The Graduate Institute of International and Development Studies, 2010.

[19] H. Hill and J. Jongwanich, "Outward foreign direct investment and the financial crisis in developing East Asia,” Asian Dev. Rev., vol. 26, no. 2, p. 1, 2009.

[20] M. P. effeCtive Coalitions, "Development Co-operation Report 2015."

[21] "Kurdistan Board of Investment.” [Online]. Available: http://www.kurdistaninvestment.org/. [Accessed: 04Feb-2021]. 